\title{
Aplikasi Model Konservasi Levine dalam Memenuhi Kebutuhan Nutrisi Bayi Prematur di Ruang Perinatologi RSUPN Dr. Cipto mangukusumo
}

\author{
Herlina $^{1}$, Yeni Rustina ${ }^{2}$, Elfi Syahreni ${ }^{3}$ \\ ${ }^{1}$ Mahasiswa Program Studi Magister Ilmu Keperawatan, Fakultas Ilmu Keperawatan universitas Indonesia \\ ${ }^{2}$ Kelompok Kelimuan Keperawatan Anak, Fakultas Ilmu Keperawatan universitas Indonesia \\ ${ }^{3}$ Kelompok Kelimuan Keperawatan Anak, Fakultas Ilmu Keperawatan universitas Indonesia
}

herlinamail@yahoo.co.id; herlina13@ui.ac.id

\begin{abstract}
Abstrak
Bayi prematur mengalami prematuritas pusat pengatur pernafasan dan kelemahan oro motor sehingga minum per oral dapat meningkatkan resiko aspirasi; sementara itu bayi prematur memerlukan asupan kalori yang lebih tinggi untuk dapat bertahan hidup dan tumbuh. Aplikasi model asuhan keperawatan Konservasi Levine dalam memenuhi kebutuhan nutrisi bayi prematur menerapkan prinsip konservasi energi, integritas struktural, personal, dan personal. Tropicognosis yang selalu muncul pada setiap kasus adalah nutrisi kurang dari kebutuhan tubuh. Wholeness tercapai ketika berat badan bayi meningkat sesuai pertumbuhan intrauterin $>15 \mathrm{~g} / \mathrm{kg} / \mathrm{hari}$. Residen menyarankan membangun peran kemitraan antara perawat, petugas kesehatan, dan keluarga serta melaksanakan asuhan keperawatan berbasis bukti penelitian.
\end{abstract}

Kata Kunci: bayi prematur, nutrisi, Model Konservasi Levine

\begin{abstract}
Premature infant had poor coordination center respiratory nerve with oro motor which cauesed higher risk of aspiration. Other wise premature infant required more calories due to maintain life system and grow up. Aplication of Levine's Model Conservation in order to meet prematur infant's nutrition requirmen. This model was content four concepts: energy conservation, conservation of structural integrity, conservation of personal integrity, and conservation of social integrity. All of cases shown Tropicognosis was nutrition less than body requirment. Wholeness was atempting when prematur infant had adequat weight gain as same as intrauterin growht more than $15 \mathrm{~g} / \mathrm{kg} / \mathrm{day}$. Pediatric nurse residen suggested for partnership health care and familly; implementation evidence based nursing practice. .
\end{abstract}

Key Words: Premature infant, nutrition, Levine’s Model Conservation 


\section{Latar Belakang}

Bayi berat lahir rendah (BBLR) menjadi salah satu masalah kesehatan di Indonesia. Data riset kesehatan dasar (RISKESDAS) tahun 2013 menunjukkan $10,2 \%$ bayi di Indonesia lahir dengan berat $<2500$ gram (Badan Penelitian dan Pengembangan Kesehatan Kementrian Kesehatan RI, 2013). BBLR dapat disebabkan oleh prematuritas (Wong, Hockenberry-Eaton, Wilson, Winkelstein, dan Schwartz, 2009). Bayi Prematuritas menjadi penyebab kematian kedua (34\%) kematian kelompok neonatus usia 0-6 hari Badan penelitian dan pengambangan kesehatan kementrian kesehatan Republik Indonesia, 2007). Bayi prematur beresiko 7,6 kali lebih tinggi mengalami komplikasi dibandingkan bayi aterm (Leone, 2011).

Komplikasi pada bayi prematur antara lain gangguan pada sistem pencernaan berupa necrotizing entero colitis (NEC), gangguan pernafasan berupa apnea, dan gangguan sistem kekebalan tubuh berupa sepsis. Bayi prematur

Karya Tulis Ilmiah ini menggunakan metode studi kasus. Residen Keperawatan Anak mengelola 5 kasus bayi preterm menggunakan pendekatan model keperawatan Konservasi Levine. Asuhan keperawatan mengintegrasikan model Konservasi Levine pada setiap proses keperawatan. Proses pengkajian mengumpulkan data berdasarkan 4 prinsip konservasi: onservasi energi, konservasi integritas struktural, konservasi integritas personal, dan konservasi integritas sosial.Residen Keperawatan Anak kemudian

Proses pengkajian mendapatkan hasil bahwa pada kelima kasus kelolaan muncul tropicognosis yang sama yaitu nutrisi kurang dari kebutuhan tubuh. Hipotesis yang diajukan oleh residen keperawatan anak antara lain: (1) Membantu pernafasan bayi dengan alat bantu nafas akan menurunkan usaha nafas yang berlebihan, sehingga bayi menghemat energi untuk bernafas; (2) Menjaga bayi berada pada suhu netral akan mengurangi kehilangan suhu harus mampu beradaptasi dengan tantangan gangguan sistem sehingga dapat bertahan hidup. Adaptasi memerlukan sumber energi yang dapat berasal dari nutrisi. Nutrisi dapat diberikan melalui per oral ataupun parenteral. Nutrisi enteral per oral meningkatkan resiko aspirasi pada bayi prematur, sedangkan nutrisi parenteral dapat menyebabkan kolestasis. Oleh sebab itu penatalaksanaan nutrisi menjadi hal yang sangat penting pada bayi prematur (Gomella, 2009).

Perawat mempunyai peranan dalam penatalaksanaan nutrisi. Asuhan keperawatan diharapkan dapat menjamin masukan energi cukup dan aman bagi bayi prematur. Model Keperawatan Konservasi Levine memfokuskan 4 konservasi dalam merawat bayi prematur antara lain: konservasi energi, konservasi integritas struktural, konservasi integritas personal, dan konservasi integritas sosial.

\section{Metode}

membuat penilaian klinis sehingga muncul tropicnosis. Hipotesis disusun untuk mengatasi tropicognosis. Intervensi disusun untuk menguji hipotesis. Evaluasi hipotesis berdasarkan respon organismik bayi. Wholeness tercapai apabila pertumbuhan bayi prematur sesuai dengan pertumbuhan janin yaitu penambahan berat badan $>15$ gram $/ \mathrm{Kg} /$ hari.

\section{Hasil}

berlebihan, sehingga bayi tidak mengeluarkan ekstra energi untuk beradaptasi dengan suhu lingkungan eksternal yang terlalu dingin mapupun terlalu panas bagi bayi; (3) Memberikan intake cairan sesuai kebutuhan akan menjamin kecukupan volume cairan tubuh bayi, sehingga bilirubin dapat dieliminasi melalui urine dan feses; (4) Foto terapi akan membantu bayi menurunkan bilirubin yang berlebihan sehingga tidak meracuni otak, menghidarakan bayi dari injuri 
otak yang berbahaya; (5) Memotivasi keluarga untuk berartisipasi dalam perawatan akan meningkatkan percaya diri keluarga untuk mampu merawat bayi; (6) Memberikan intake nutrisi sesuai kebutuhan bayi akan memberikan energi yang cukup untuk memenuhi peningkatan kebutuhan energi; dan (7) Energi yang cukup akan memberikan kesempatan bayi untuk meningkatkan berat badan.

Intervensi keperawatan disusun berdasarkan 4 prinsip konservasi: (1) Konservasi energi; (2) konservasi integritas struktural; (3) Konservasi integritas personal, dan (4) Konservasi integritas sosial. Intervensi konservasi energi dengan manajemen nutrisi mempertimbangkan integritas struktural sistem pernafasan, sistem kekebalan tubuh, dan sistem termoregulasi. Konservasi integritas personal dilakukan dengan memberikan stimulus oral dan taktil sesuai tahap perkembangan bayi. Konservasi integritas sosial dengan mengoptimalkan fungsi keluarga.

Tindakan keperawatan yang telah dilakukan untuk memenuhi kebutuhan nutrisi bayi prematur antara lain: mengkaji reflek hisap untuk mengevaluasi kesiapan minum per oral, menjaga suhu lingkungan bayi tetap hangat untuk mencegah kehilangan energi bayi, memonitor toleransi minum bayi, menimbang berat badan bayi tiap 3 hari sekali, melibatkan keluarga untuk persediaan ASI, dan kolaborasi dengan dokter untuk penatalaksanaan nutrisi bayi.

Wholeness tercapai pada kelima kasus. Kasus kelolaan utama mengalami peningkatan berat badan mencapai 27 gram/hari.

\section{PEMBAHASAN}

Bayi prematur mengalami kesulitan pada saat minum per oral yaitu sulit mengkoordinasikan kegiatan menghisap-menelan-bernafas (Gomella, 2009). Keterampilan minum bayi prematur dapat dikaji menggunakan instrumen Early Feeding Skill/EFS (Thoyre, Shaker, \& Pridham, 2005). Minum per oral merupakan proses yang sangat komplek pada bayi prematur. Proses minum peroral melibatkan koordinasi pernafasan dengan kegiatan motorik otot oro motor untuk menghisap dan menelan. Reflek menelan tmulai muncul usia gestasi 15 minggu dan reflek hisap berkembang secara konsisten pada usia gestasi 22-24 minggu. Koordinasi pusat pernafasan untuk menghisapmenelan-bernafas terjadi pada usia gestasi 28 minggu tetapi masih beresiko mengalami kegagalan koordinasi. Kegagalan koordinasi ini meningkatkan resiko aspirasi pada bayi prematur. Koordinasi dapat dinilai dengan mnggunakan EFS assesment. Bayi siap minum per oral pada usia gestasi 32-34 minggu (Breton \& Steinwender, 2008; Jones, 2012).

Variasi usia gestasi terlihat pada kelima kasus kelolaan. Kasus 1 lahir pada usia gestasi 29 minggu, kasus kedua 30 minggu, kasus ketiga 36 minggu, kasus keempat 36 minggu, dan kasus kelima 33 minggu. Kelima bayi prematur lahir pada usia gestasi $>28$ minggu yaitu usia yang telah mampu mengkoordinasikan pernafasan dengan proses menghisap dan menelan tetapi masih beresiko terjadi kegagalan koordinasi. Reflek menghisap pada kasus ketiga dan keempat baik (usia gestasi 36 minggu) sedangkan reflek hisap lemah pada kasus pertama, kedua dan kelima (29, 30, dan 33 minggu gestasi). Reflek hisap bayi Ny S (kasus 1) baik pada usia kronologis $33+5$, dibuktikan dengan nilai EFS 10. Kemampuan minum bayi baik sehingga dilepas OGT dan bayi minum per oral. Skor EFS 10 menunjukkan bahwa bayi Ny $\mathrm{S}$ mempunyai kecukupan energi untuk menyusu dan kecil resiko aspirasi. Upaya untuk mengurangi resiko aspirasi dengan memberikan minum per OGT sehingga nutrisi dapat masuk langsung ke dalam sistem pencernaan tanpa melalui koordinasi pernafasan.

Sistem pencernaan bayi prematur mengalami imaturitas. Sistem pencernaan juga berfungsi sebagai sistem pertahanan tubuh. Bayi prematur mengalami penurunan sekresi imunoglobulin A yang melindungi lapisan mukosa lumen usus. Imaturitas fisiokemikal 
luminal mensekresi sedikit ion hidrogen. Imaturitas juga menyebabkan rendahnya enzim proteolitik pankreas, enterokinase, sehingga menekan hidrolisis kuman. Kuman yang tidak terhidrolisis akan mengeluarkan toksin. Toksin akan lama berada di dalam lumen usus karena bayi prematur mengalami dismotilitas intestinal. Dismotilitas intestinal lebih sering terjadi pada bayi prematur dengan usia gestasi $<34$ minggu. Penurunan sekresi imunoglobulin A, enterokinase, dan dismotilitas intestinal meningkatkan resiko kerusakan jaringan yang memicu terjadinya NEC (Josef, 2007; Gurllet, Stoll, dan Cotten, 2006).

NEC terjadi pada kasus kelima, bayi nyonya NA 1. Bayi lahir prematur pada usia gestasi 33 minggu. NEC dibuktikan dengan hasil foto rontgen abdomen. Infeksi dibuktikan dengan nilai C-reactif protein (CRP) yang meningkat (CRP 0,6). Dismotilitas akan meningkatkan waktu transit makanan dan toksin sehingga perlu feeding yang aman.

Feeding pada bayi harus aman sehingga mempertimbangkan beberapa kriteria untuk memulai feeding. Feeding yang dimulai sejak dini akan menstimulasi pelepasan hormonhormon enterik yang akan memunculkan efek trofik pada saluran intestinal. Feeding dapat mengakibatkan NEC pada bayi yang mengalami asfiksia, instabilitas hemodinamik, sepsis, dan patens duktus arteriosus/PDA. Pemilihan formula feeding penting untuk menghindari NEC. ASI merupakan pilihan utama untuk feeding bayi aterm, prematur, dan bayi sakit. ASI mengandung Ig A, Ig G, dan Ig $M$ yang akan meningkatkan sistem kekebalan tubuh bayi. Resiko NEC meningkat 6-10 kali lebih tinggi pada bayi yang menggunakan susu formula. Tropic feeding dapat mengurangi resiko NEC. Metode tropic feeding dapat dilakukan dengan OGT. Volume tropic feeding bervariasi mulai dari $0,1 \mathrm{~s} / \mathrm{d} 24 \mathrm{ml} / \mathrm{kg} / \mathrm{hari}$ (Gomela, 2009).

Kasus kelima, Bayi Nyonya NA 1 mendapat nutrisi parenteral PG1 dilanjutkan PG2 melalui PICC. Hasil kultur darah PICC menunjukkan isolet steril, tidak ada infeksi sehingga tidak memperberat NEC. Nutrisi enteral dimulai dengan tropic feeding. Tropic feeding menggunakan metode OGT. Volume feeding mulai $2 \times 1$ cc ASI pada awal pemberian kemudian meningkat $4 \times 1 \mathrm{cc}$. Ig A dari ASI membantu memperbaiki membran mukosa intestinal sehingga meminimalkan kontak toksin bakteri dengan membran mukosa. Protein ASI akan menstimulasi sekresi enzime proteolitik pankreas. Protein kuman akan ikut terhidrolisis oleh enzime proteolitik pankreas sehingga mengurangi toksin. Peningkatan volume di dalam intestinal akan menstimulasi gerak peristaltik/motilitas usus sehinga toksin di dalam lumen dapat dimobilisasi keluar tubuh. Feeding tidak memperburuk NEC. Perbaikan NEC dibuktikan dengan foto rontgen abdomen.

Kebutuhan nutrisi bayi prematur terdiri dari kebutuhan kalori, karbohidrat, protein, lemak, vitamin, mineral, dan cairan. Kalori yang dibutuhkan untuk mempertahankan berat badan bayi $50-60 \mathrm{kkal} / \mathrm{kg} / \mathrm{hari}$. Bayi prematur memerlukan 110-140 kkal/kg/hari untuk meningkatkan berat badan. Pertumbuhan bayi prematur adekuat apabila penambahan berat badan sama dengan penambahan berat badan intra uterin atau $15 \mathrm{~g} / \mathrm{kg} /$ hari. Kebutuhan karbohidrat 10-30 g/kg/hari mampu mencukupi $40-50 \%$ dari total kalori. Intake protein adekuat 2,25-4 g/kg/hari mencukupi 7-16\% total kalori. Intake protein sebaiknya $<4,0$ $\mathrm{g} / \mathrm{kg} /$ hari. Kebutuhan lemak 5-7 g/kg/hari. (Gomela, 2009).

Penambahan berat badan kasus kelolaan 1 dan keempat adekuat karena $>15 \mathrm{gr} /$ hari. Kasus keempat, Bayi nyonya D, meningkat 15,2 gr/hari. Bayi.Ny D mendapat intake kalori $153,31 \mathrm{kkal} / \mathrm{hari}$ dari TPN PG2 8,3ml/jam, D10+ca 4,1 ml/jam, IL 20\% 1,4 ml/jam. Jumlah kalori ini memenuhi kebutuhan kalori bayi prematur untuk tumbuh. Pertumbuhan Bayi.Ny D dibuktikan dengan meningkatnya berat badan dari 1990 menjadi 2035 gram. Bayi.Ny D mulai minum peroral dan mampu mentolerir nutrisi enteral ASI sampai dengan mencapai volume $8 \times 15 \mathrm{ml}(120 \mathrm{ml} / \mathrm{hari})$. Toleransi 
minum Bayi.Ny D dimanifestasikan dengan tidak ada kembung dan tidak ada muntah.

Kasus kelolaan utama, bayi Nyonya S, mendapatkan intake kalori $116 \mathrm{kkal} / \mathrm{hari}$ pada usia 4 hari. Jumlah kalori ini cukup untuk meningkatkan berat badan bayi prematur tetapi hasil timbang berat badan menunjukkan berat badan turun $4,8 \%$. Penurunan ini fisiologis pada usia $<7$ hari. Pada usia kronologis 30 minggu +5 hari bayi mendapat intake kalori sebesar $132 \mathrm{kkal} / \mathrm{hari}$ dari program nutrisi enteral ASI $12 \times 8$ cc (64 kkal) dan parenteral PG2 $(2,1 \mathrm{gr} / \mathrm{kg} / \mathrm{hari})$ rate $3,2 \mathrm{ml} / \mathrm{jam}$, IL $20 \%$ $(1,5 \mathrm{gr} / \mathrm{kg}) \quad 0,4 \mathrm{ml} / \mathrm{jam}$. Nutrisi parenteral mensuplay energi dari intake karbohidrat sebesar 7,68g/hari $(30,72 \mathrm{kkal})$, intake protein, 2,4 g/hari ( 21,92 kkal), dan intake lemak 1,74 $\mathrm{g}(15,66 \mathrm{kkal})$. Toleransi minum per oral bayi baik sehingga bayi mendapat cukup suplay energi sehingga berat badan meningkat 170 gram. Peningkatan ini belum dapat mengembalikan berat lahir bayi. Berat lahir bayi kembali pada usia kronologis 31 minggu. Pada usia kronologis 32 minggu penambahan berat badan sebesar 15 gram/hari. Bayi pulang ke rumah pada usia kronologis 33 minggu dan saat kontrol ke poliklinik usia 35 minggu. Berat badan pada usia kronologis 35 minggu 2300 gram. Penambahan berta badan 27 gram/hari. Apabila penambahan berat badan konstan maka bayi mampu mencapai berat $>2500$ gram pada usia kronologis 37 minggu. Pertumbuhan bayi Ny S adekuat karena sesuai dengan pertumbuhan intrauterin yaitu 15 gr/kg/hari sehingga pada usia aterm berat lahir $>2500$ gram.

Residen merawat bayi nyonya S menggunakan pendekatan model konservasi Levine pada setiap proses keperawatan. Integrasi model konservasi Levine dalam proses keperawatan mencakup kegiatan pengkajian, Judgment/tropicognosis, hypothesis, intervensi, dan evaluasi. Proses pengkajian mengumpulkan data berdasarkan prinsip konservasi menghasilkan fakta profokativ. Perawat mengobservasi pasien terkait respon organismik terhadap penyakit, membaca riwayat medis, pemeriksaan penunjang, dan berbicara dengan pasien tentang kebutuhan bantuan. Perawat mengkaji tantangan lingkungan internal dan eksternal. Perawat mengkaji tantangan yang terkait dengan (1) keseimbangan suplay dan kebutuhan energi, (2) sistem pertahanan tubuh, (3) perasaan dan hubungan antar manusia, dan 4) kemampuan berpartisipasi dalam sistem sosial. Variabel yang terkait dengan konservasi energi antara lain: cemas, saturasi oksigen, gula darah, nadi, suhu tubuh, pernafasan, tekanan darah, hemoglobin dan hematokrit, turgor kulit, cairan dan elektrolit, panas, pertukaran energi, diare, perdarahan, berat badan, dan drainage luka (Alligood \& Tomey, 2006; Fawzet dan Madeya, 2013).

Residen mengkaji berdasarkan 4 prinsip konservasi. Residen mengkaji bayi nyonya $\mathrm{S}$ (kasus 1) dan mendapatkan data profokativ dari prinsip konservasi energi sebagai berikut: Usia gestasi 29 minggu, berat lahir 1460 gram, panjang badan $51 \mathrm{~cm}$, lingkar kepala $28 \mathrm{~cm}$, lingkar lengan atas $8 \mathrm{~cm}$, albumin $3,54 \mathrm{~g} / \mathrm{dl}$. Residen menilai data profokativ tersebut dan memunculkan tropicognosis nutrisi kurang dari kebutuhan tubuh. Bayi mendapat tantangan dari lingkungan intenal yaitu prematuritas. Bayi prematur tidak mampu memproduksi panas dengan efektif. Disisi lain bayi memerlukan energi lebih banyak untuk mematangkan sistem dan pertumbuhan. Dengan demikian terjadi ketidak seimbangan antara suplai dan out put energi. Residen menilai kondisi ketidak seimbangan energi ini berbahay dan bayi membutuhkan bantuan untuk menyeimbangkan energi kembali. Residen tidak mengkonfirmasi penilaian ini kepada bayi karena bayi belum dapat diajak bicara. Residen mengajukan hipotesis 2 hipotesis: (1) Memberikan intake nutrisi sesuai kebutuhan bayi akan memberikan energi yang cukup untuk memenuhi peningkatan kebutuhan energi, dan (2)Energi yang cukup akan memberikan kesempatan bayi untuk meningkatkan berat badan. Hipotesis ini diuji oleh residen dengan intervensi keperawatan: menjaga suhu netral lingkungan bayi $\left(34^{\circ} \mathrm{C}\right)$, menimbang berat badan 3 hari sekali, memonitor toleransi minum bayi, 
berkolaborasi untuk terapi cairan, dan memonitor hasil laboratorium.

Residen mengkaji bayi nyonya S (kasus 1) dan mendapatkan data profokativ dari prinsip konservasi struktural sebagai berikut: Usia gestasi 29 minggu, frekuensi pernafasan 48 $\mathrm{x} / \mathrm{mnt}$ teratur, terdapat penggunaan otot bantu pernafasan interkosta sehingga tampak retraksi dada minimal, riwayat nafas cuping hidung, Usia Gestasi 29 minggu, frekuensi nadi $169 \mathrm{x} / \mathrm{mnt}$, Capilary refill time $<2$ detik, hemoglobin $16,4 \mathrm{~g} / \mathrm{dl}$, hematokrit 48,4, eritosit 4,51, trombosit 270.000,leukosit 13.210, IT rasio 0,06, dan CRP 0,4 mg/l, riwayat ketuban pecah 4 hari, bayi tampak ikterik, dan kreamer grade I-II. Residen menilai data profokativ ini dan mengajukan tropocognosis sebagai berikut: (1) gangguan pola nafas, (2) gangguan termoregulasi, (3) resiko ketidakefektifan perfusi jaringan, (4) resiko infeksi (lanjut), (5) resiko cedera internal. Hipotesis yang diajukan oleh residen antara lain: (1) membantu pernafasan bayi dengan alat bantu nafas akan menurunkan usaha nafas yang berlebihan sehingga bayi menghemat energi untuk bernafas, (2) menjaga bayi berada pada suhu netral akan mengurangi kehilangan suhu berlebihan sehingga bayi tidak mengeluarkan ekstra energi untuk beradaptasi dengan suhu lingkungan eksternal yang terlalu dingin mapupun terlalu panas bagi bayi, (3) memberikan intake cairan sesuai kebutuhan akan menjamin kecukupan volume cairan tubuh bayi sehingga bilirubin dapat dieliminasi melalui urine dan feses, (4) foto terapi akan membantu bayi menurunkan bilirubin yang berlebihan sehingga tidak meracuni otak, menghidarkan bayi dari injuri otak yang berbahaya.

Residen mengkaji bayi nyonya S (kasus 1) dan mendapatkan data profokativ dari prinsip konservasi struktural sebagai berikut: bayi dirawat terpisah dengan ibu, ibu bayi belum menjenguk bayi karena kondisi fisik masih lemah post operasi SC, ayah bayi datang menjenguk dan menanyakan kondisi bayi, ayah bayi menyatakan bahwa kakak bayi selalu menanyakan adiknya, kakak bayi tidak dapat menjenguk adiknya karena anak-anak dilarang masuk ke ruang rawat bayi, bayi ini merupakan pengalaman keluarga yang pertama kali merawat bayi prematur. Residen menilai data profokativ tersebut dan muncul tropicognosis gangguan proses keluarga.

Residen mengevaluasi uji hipotesis dengan menilai respon organismik. Respon organismik yang muncul sebagai berikut: berat bayi 2300 gram, penambahan berat badan 27 gram/hari, toleransi minum baik. Berdasarkan respon organismik tersebut residen menyimpulkan bahwa respon organismik mendukung hipotesis.

Residen tidak mengkaji integritas personal secara khusus. Meleis, 2007, menyatakan variabel yang terkait dengan integritas personal adalah sosialisasi, perkembangan moral, dinamika kelompok, dan isolasi sosial. Perkembangan moral akan berkmbang ketika telah terjadi perkembangan kognitif. Perkembangan kognitif bayi baru lahir belum berkembang sehingga perkembangan moral belum terjadi. Perkembangan psikososial berada pada tahap trust vs mistrust sedangkan perkembangan psikoseksual berada pada fase oral. Organ sensori paling besar bayi adalah mulut, sehingga dengan terapi nutrisi enteral melalui minum per oral diharapkan dapat memberikan stimulus oral sehingga bayi dapat merasa puas. Selanjutnya bayi akan mengembangkan kepribadian trust. Perasaan kesendirian bayi mungkin muncul karena bayi dirawat terpisah dengan ibu. Perasaan ini diminimalkan dengan melibatkan keluarga dalam perawatan bayi, memfasilitasi keluarga untuk menyentuh dan mengajak bicara bayi untuk stimulasi perkembangan bayi. Nest membantu mengurangi perasaan kesendirian bayi karena memberikan sensasi sentuhan di sekitar kulit bayi sehingga bayi merasa terlindungi, aman, sebagaimana lingkungan intrauterinnya dulu

Contemporary nursing knowledge: Analysis and evolution of nursing model and theoriest. Philadelphia: F.A Davis Company

\section{Simpulan}


Nutrisi merupakan masalah keperawatan yang terjadi pada semua bayi prematur. Penatalaksanaan minum per oral harus aman untuk bayi prematur. Model konservasi Levine dapat diaplikasikan untuk merawat bayi prematur. Wholeness tercapai ketika pertumbuhan bayi adekuat yang ditandai dengan penambahan berat badan $>15 \mathrm{~g} / \mathrm{kg} / \mathrm{hari}$.

\section{Kepustakaan}

Alligood, M. R. (2014) . Nursing theorist and their work. St Louis: Elsevier Inc

Alligood, M. R, \& Tomey, A. M. (2006) . Nursing theory:Utilization \& aplication. St Louis : Mosby

Amendolia, B. (2011). An integrative review of feeding intolerance in preterm infants: State of the sciensce. Clinical Scholars Review. 4(2).82-90. Doi: 10.1891/1939-2095

Breton, S., Steinwender, S. (2008). Timing introduction and transition to oral feeding in preterm infants: Currnt trends and practice. Newborn Infant Nurs Review;8(3):153-159

Brodsky, D., \& Ouellette, M. A. (2008). Primary care of the premature infant. Philadelphia: Saunders

Badan penelitian dan pengembangan kesehatan kementrian kesehatan RI. (2013). Riset dasar kesehatan/riskesdas 2013. Jakarta: Kemenkes

CSPEN. (2013). CSPEN guidelines for nutrition support in neonates. Asia Pacifik Jurnal Clinical Nutrition; 22(4):655-663

Josef, N. (2009). Gastrointestinal development and meeting the nutritional needs of
Fanaroff, A. A. ( 2010). Late preterm infantsproblems and their prevention. Neonatology Formerly Biology of The Neonate. 93-379. Doi: $10.1159 / 000297769$

Fawcet, J., Madeya, S. D. S. (2013).

Gewolb, J. H., \& Vice, F. L. (2006). Abnormalities in the coordination of respiration and swallow in preterm infants with bronchopulmonary dysplasia. Developmental Medicine \& Child Neurology;48(7):595-599

Gomella, T. L. (2009). Neonatology management, procedures, on-call, problems, diseases, and drugs. New York: Mc Graw Hill Companies

Gurllet, R., Stoll, B. J., Cotten, C. M. (2006). Association of $\mathrm{H} 2$ blocker theraphy and higher incidence of necrotizing enterocolitis in very low birth weight infant. Pediatrics;117:eI37-42

Hull, D., Johnston, D. (2008). Dasar-dasar pediatri. Edisi 3. Jakarta: EGC

Jiang P, Jensen ML, Cilieborg MS, Thymann T, Wan JM-F, Sit, W. H., Ipoe, G. L., \& Sangild, P.T. (2012). Antibiotics Increase Gut Metabolism and Antioxidant Proteins and Decrease Acute Phase Response and Necrotizing Enterocolitis in Preterm Neonates. PLoS ONE;7(9):e44929.

doi:10.1371/journal.pone.0044929

Jones, L. R. (2012). Oral feeding readiness in the neonatal intensive care unit. Neonatal Network;31(3):148-155.Doi: 10.1891/0730-0832.31.3.148

prematur infants. The American Journal of Clinical Nutritional;85:629s-634s 
Lau, C., \& Smith, E. O. (2011). A novel approach to assess oral feeding skill of preterm infants. Neonatology; 100:6470. Doi: $10.1159 / 000321987$

Leone, A., Ersfeld, P., Adams, M., Schiffer, P. M., Bucher, H. U., \& Arlettaz, R. (2012). Neonatal morbidity in singleton late preterm infantscompared with fullterm infants. Foundation Acta Pediatrica, 101, 6-10.

Meadow, R., \& Newell, S. (2005). Lecture notes pediatrika. Edisi 7. Jakarta: Penerbit Erlangga

Mefford, L. C., Alligood, M. R. (2013). Testing a theory of health promotion for preterm infants based on levine's conservation model of nursing. The Journal of Theory Construction \& Testing;15(2):41-47

Meleis, A. I. (2007) . Theoritical nursing developmen and progress. Philadelphia: Lipincott William \& Wilkins

Ning-Yu, C., Ting-Yu, L., Ya-Jing, L., \& Yuan, T. (2013). A nursing case experience using levine's conservation model to provide sepsis care. $\mathrm{Hu} \mathrm{Li} \mathrm{Za}$ Zhi;60(2):1 03-10
Rogers, R., \& Arvedson, J. (2005). Assessmenof infant oral sensorimotor and swallowing function. Mental Retardation and Developmental Disabilities Research Reviews; 11(1):74-82

Rohen, W. R., Drecoll, E. L. (2009). Embriologi fungsional: Perkembangan sistem fungsi organ manusia. Edisi 2. Jakarta: EGC

Schalder, G., Burghart, H. S., Toschke, A. M., VonVoss, H., \&VonKries, R. (2007). Feeding disorders in ex-prematures: Causes-response to therapy long term outcome. European Journal Pedoatric. 166:803-808. Doi:10.1007/s00431-006$0322-\mathrm{x}$

Thoyre, S. M., Shaker, C. S., \& Pridham, K. F. (2005). The early feeding skills assessment for preterm infants. Neonatal Network; 24 (3): 7-16

Wong, D. L., Hockenberry-Eaton, M., Wilson, D., Winkelstein, M. L., \& Schwartz, P. (2009). Buku ajar keperawatan pediatrik wong. 